A. В. Санкин [A. V. Sankin]

\title{
МЕТОД НАПОРНОЙ ФЛОТАЦИИ. РАСЧЕТНАЯ ОЦЕНКА РАЗМЕРОВ И ФОРМЫ ИЗВЛЕКАЕМЫХ ТОНКИХ ФРАКЦИЙ ДРАГМЕТАЛЛОВ
}

\section{PRESSURE FLOTATION METHOD. THE ESTIMATED ASSESSMENT OF THE SIZE AND SHAPE OF RECOVERABLE FINES OF PRECIOUS METALS}

Институт сервиса, туризма и дизайна (филиал) СКФУ в г. Пятигорске, Пятигорск, Россия Institute of Service, Tourism and Design (branch) NCFU in Pyatigorsk, Pyatigorsk, Russia

Аниотация. В работе рассмотрен процесс извлечения частиц драгоценных металлов методом напорной флотации. Произведены оченочные расчеть размеров и массы поднимаемых частии золопа из отвалов. Приведены выводы, позволяющие определить применение метода напорной флотаџии в зависимости от применяемого сырья, содержащего мелкие фракиии золота.

Материаль и методы. НІовый метод извлечения тонких фракиий драгоченных металлов (например, из рудньхх пульп) на первом этапе включает в себл обработку пульпь флотореагентами с иелью гидрофобизаиии поверхиости извлекаелых избранных частиц. При работе по этому методу вода предварительно должна насыщаться воздухом под давлением. Далее подготовленнал кондициониованная пильпа смеиивается с водой, сатурированной воздухом при атмосферном давлении. Затем эту смесь обрабатьвают потоком пузырьков воздуха соответствующих флопационньх размеров.

Заключение. Предложенная технология, в основе коморой используется метод напорной флотаиии [7] может применяться для извлечения тонких фракций драгоценньх металлов, которые не могут извлекаться методом классической флотации. Но это происходит только с ограниченными типами сырья с извлекаемыми частицами определенной формы и размеров.

Выводы. Задача извлечения тонких фракиий драгоченных металлов может бытьь решена посредством приленения новой технологии, сырьем для которой является пластинчатое золото, илеющее необходимые геометрические параметры и размеры, рассчитанные в данной статье. Показано, что данныл методом можно извлекать пластинчатое золото с толщиной от 0,005 (мм) и менее.

Клочевые слова: флотационные методы, флотореагент, обогапение золотосодержапего сырья, пульпа, гидрофобные частицы.

Abstract. The process of extracting fines of precious metals by the method of pressure flotation is considered in the paper. Estimated calculations of the size and mass of the raised from the dumps gold fines were made. The author gives the conclusions that allow to determine the application of the pressure flotation method depending on the used raw materials containing fine gold fractions.

Materials and methods. A new method for extracting fine fractions of precious metals (for example, from ore pulps) at the first stage includes treating the pulp with flotation reagents in order to hydrophobize the surface of the selected fines to be extracted. When using this method, the water must first be saturated with air under pressure. Then the prepared conditioned pulp is mixed with water saturated with air at atmospheric pressure. Then this mixture is treated with a stream of air bubbles of appropriate flotation sizes.

Results. The proposed technology, based on the method of pressure flotation [7], can be used to extract fine fractions of precious metals that cannot be extracted by the method of classical flotation. But this method is applicable only for a limited type of raw material with recoverable fines of a certain shape and size.

Conclusions. The task of extracting fine fractions of precious metals can be solved by using a new technology, the raw material for which is plate gold, which has the necessary geometric parameters and dimensions calculated in this article. It is considered that this method can be used to extract plate gold with a thickness of 0.005 ( $\mathrm{mm})$ and less.

Key words: flotation methods, flotation agent, enrichment of gold-bearing raw materials, pulp, hydrophobic particles.

Introduction. Flotation methods of ore beneficiation are based on the use of the kinetic component, which is expressed in the inertial motion of hydrophobized fines during the implementation of the elementary flotation action hitting an air bubble and sticking to it with the formation of a floating particle-bubble aggregate. In all these cases, particle size is critical. With a decrease in the size of the particles, their kinetic component decreases and they become unable to perform an elementary flotation action. As follows from literary sources, from 40 to $50 \%$ of unrecovered gold of fine fractions remains in the tails of gold placers enrichment [1].

The flotation method operates on the principle of adhesion of hydrophobized particles of individual minerals to air bubbles in the pulp environment through their collision. With this interaction, the formed particle-bubble aggregates float to the surface of the pulp under the action of the Archimedean force. The result is foam that is discharged into the tank. Further, the resulting foam is dehydrated to obtain a product - a concentrate of the extracted mineral particles. The remaining depleted slurry from the chamber is discharged in the form of flotation tailings into a storage facility. In this case, the pulp before the flotation process is treated with specially selected flotation reagents, which convert the particles of selected minerals into hydrophobic particles subject to flotation. The particles of the remaining minerals turn into hydrophilic, water-wetted, and therefore non-floatable particles [2].

By dispersing atmospheric air in the pulp, appropriate conditions are created for the adhesion of hydrophobized particles with air bubbles in the pulp. The adhesion of the obtained hydrophobized particles to air bubbles with their 
subsequent retention on the surface occurs under the action of the forces of intermolecular interaction. These forces exist on the surfaces of a floating particle and bubble in the form of surface free energy created by uncompensated forces of molecules and atoms located on this surface [3, 8].

The action of van der Waals forces begins to manifest itself at a distance of $1000 \mathrm{pm}$ (picometers $1 * 10-12 \mathrm{~m}$ ), and their maximum effect occurs at a distance of $500 \mathrm{pm}$, but further convergence of reacting particles is counteracted by the repulsion of electrons of molecules of approaching particles [4,5].

As the mass of hydrophobized particles decreases to less than $0.05 \mathrm{~mm}$, the inertial forces of such particles are weakened, and it becomes more difficult for them to break through the hydration layers and the elementary effect of flotation of these small particles does not occur, therefore, they will not float. But the flotation of such particles is of great importance for the beneficiation of gold-bearing sands, in which a significant part of the precious metals is in the form of fine particles less than $0.05 \mathrm{~mm}$ in size, which are not recovered either by gravity or flotation methods [6, 9]. That is why a number of sources indicate that when such sands are enriched, up to $50 \%$ of the gold contained in them is not recovered and goes into the tailings. Consequently, raw materials from such deposits require a new method of flotation, in which air bubbles would stick to such small particles and be carried out into the foam layer [10].

As the external pressure decreases, the gas solubility in the liquid decreases. In the technological process of flotation, an aqueous solution of air created under pressure, being at atmospheric pressure, turns out to be supersaturated with air and unstable. In this case, the excess dissolved air begins to pass from the solution into the gas phase. Such a phase transition occurs in the form of very small bubbles, the nuclei of which can form and grow on hydrophobic particles by diffusion of air from the solution medium. This occurs by shifting the H2O molecules from the hydrophobic surface. If there are not enough hydrophobic particles, very small bubbles will begin to emerge in the total volume of water. This is due to the fact that on the hydrophobic surface, the particles, attracted water molecules, have a weak bond with it, and the nuclei of small bubbles formed on this surface can shift them without high energy consumption [11]. And with the appearance of nuclei of air bubbles in the total volume of water and their further growth, they need to destroy the strong bonds of polar $\mathrm{H} 2 \mathrm{O}$ molecules, at significantly higher energy consumption.

The process of pressure flotation can continue as long as particles with a free hydrophobic surface area and the remainder of an aqueous solution supersaturated with air remain in the initial pulp. And only in the process of reducing the area of particles with a hydrophobic surface can the energy-intensive process of the appearance of air bubbles in the total volume of the aqueous phase of the pulp occur. In this regard, the process of obtaining a mixture of conditioned pulp with water, previously saturated with air, must be of high quality. In this case, the resulting mixture of saturated water with the aqueous phase of the pulp should be evenly distributed over the volume of the pulp. But, due to the small size of the resulting mini-particle-bubble aggregates, which have a low ascent rate, the pulp must be constantly processed with flows of air bubbles of appropriate sizes for transportation.

A patent for an invention No. 2507007 dated 20.02.2014. "A method of extracting selected minerals from ore pulps by pressure flotation and a device for its implementation is received on this subject." [7]

When working with gold-bearing raw materials, it should be taken into account that the density of gold is high $-\rho=1.96 \cdot 104(\mathrm{~kg} / \mathrm{m} 3)$. In order to lift a gold particle from the pulp, it is necessary to have a buoyancy force obtained due to the adhesion of air bubbles to it with a total volume of approximately 20 times the volume of this gold particle.

The surface of a gold particle must be covered in the general case with at least 20 bubbles of the same volume each as the original gold particle. Theoretically, it is possible to assume the shape of a gold particle in the form of a cube (grain) with 6 faces, which will allow only 6 air bubbles of the corresponding volume to be attached to the surface, while the calculation requires at least 20 bubbles of the same volume to lift a particle. In this case, particles of a substance with a density not exceeding $6(\mathrm{~kg} / \mathrm{m} 3)$ can be subjected to flotation - according to the number of particle faces. Therefore, the flotation process is highly dependent on the shape of the gold particle (for example, in the form of flakes).

Let's make the necessary calculations. Let's designate the average geometric parameters of a cube-shaped particle (length, width, height): $1=0.05(\mathrm{~mm})=510-5(\mathrm{~m})$. The volume of such a particle is $\mathrm{V}$ aurum $=13=12510-15$ $(\mathrm{m} 3)$. The density of gold is $\rho$ aurum $=19.3(\mathrm{~g} / \mathrm{cm} 3)=19.3103(\mathrm{~kg} / \mathrm{m} 3)$.

Let us determine the mass of the selected gold particle $\mathrm{m}=\mathrm{V}$ aurum $\cdot \rho$ aurum $=125 \cdot 10-15 \cdot 19.3 \cdot 103=$ $241.25 \cdot 10-11(\mathrm{~kg})$.

Particle weight is $\mathrm{P}=\mathrm{m} \cdot \mathrm{g}=241,25 \cdot 10^{-11} \cdot 9,81 \approx 2,510^{-8}\left(\mathrm{~kg} \cdot \mathrm{m} / \mathrm{c}^{2}\right)$. Here $\mathrm{g}=9,81\left(\mathrm{~m} / \mathrm{c}^{2}\right)$.

At the same time, we take the density of water $\rho=1\left(\mathrm{~g} / \mathrm{cm}^{3}\right)=1 \cdot 10^{3}\left(\mathrm{~kg} / \mathrm{m}^{3}\right)$. The lifting force acting on the gold particle must be higher than its weight, therefore, the volume of the air bubbles participating in the rise must be proportionally larger than the volume of the gold particle due to the difference in density between the water and the lifted particle. $\mathrm{P}=\mathrm{m} \cdot \mathrm{g}=\rho_{\text {water }} \cdot \mathrm{V}_{\text {water }} \cdot \mathrm{g} \approx \rho$ aurum $\mathrm{V}$ aurum $\cdot \mathrm{g}\left(\mathrm{kg} \cdot \mathrm{m} / \mathrm{c}^{2}\right) ; \mathrm{V}$ air $>20 \cdot \mathrm{V}$ aurum.

As a result, the total volume of air bubbles should be more than 20 times greater than the volume of a grain of gold, determined by the difference in the density of water and the floating element.

From the above calculations, it can be seen that for the example of a particle with a face size of $0.05(\mathrm{~mm}) \mathrm{x}$ $0.05(\mathrm{~mm})$, the volume of the particle will be V particle $=125 \cdot 10^{-15}\left(\mathrm{~m}^{3}\right)$. To lift such a particle, an air volume of at least 20 times is required. $\mathrm{V}$ air. $=20 \cdot \mathrm{V}$ particle $=20 \cdot 125 \cdot 10^{-15}=250 \cdot 10^{-14}\left(\mathrm{~m}^{3}\right)$. 
If a particle of a given volume is divided into 10 thin plates, then 20 air bubbles (on top of the plate and bottom of the plate) necessary for lifting can be placed on it, placed on the corresponding area (see Fig. 1). In this case, the particle has the same mass, but a much larger surface. This allows the particle to be lifted, since the number of bubbles will provide the required lifting force. Thus, the shape of the particle affects its rise.

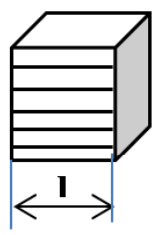

a)

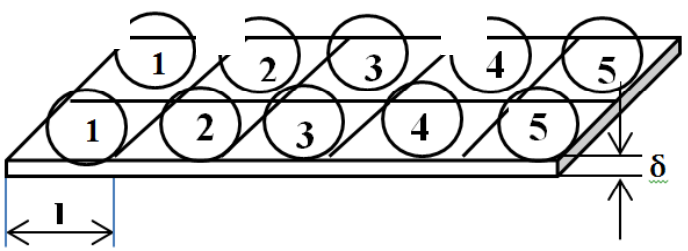

b)

Fig. 1. Elementary particle for lifting by pressure flotation. a) a particle of a cubic shape; b) a plate-shaped particle (bubbles are shown only on one upper side of the plate)

Conclusion. As a result, the following conclusions can be drawn:

1. For lifting gold particles by the method of pressure flotation, a promising raw material can be mainly plate gold, which has the necessary geometric parameters and dimensions.

2. This method can only lift plate gold with a thickness of $1=0.005(\mathrm{~mm}) ; \delta=0.005(\mathrm{~mm})$.

3. Materials with a density $\rho<6\left(\mathrm{~g} / \mathrm{cm}^{3}\right)$ can be lifted in the form of grains, because sufficient lifting force will be provided by the total number of bubbles attached to the particle.

\section{ЛИТЕРА ТУРА}

1. Глембоцкий В.А. Классен В.И. Флотационные методы обогацения. М. «Недра», 1981.

2. Абрамов А.А. Флотационные методы обогащения. М.: Горная книга, 2008. 711c.

3. Патент №2155716. Опубол. 16.09.2000 г. Бюл. №25.

4. Патент №87159 на полезную модель. Опубл. 27.09.2009 г. Бюл. №27.

5. Шило НІ.А. Учение о россыпях. Теория россыпеобразующих рудных формаций и россыпей. Владивосток, Дальнаука, 2002. $473 \mathrm{c}$.

6. Электронный ресурс: www.twellgroup.ru

7. Патент на изобретение №2507007 от 20.02.2014г. «Способ извлечения избранных минералов из рудных пульп напорной флотацией и устройство для его осуществления».

8. Atkinson B.W., Conway C.J. and Jameson G.J. High Efficiency Flotation of Coarse and Fine Coal, paper presented at: High Efficiency Coal Preparation Symposium, SME annual Meeting, AIME $124^{\text {th }}$ Annual Meeting, March 6-9, Denver, Colorado, USA (1995).

9. Богданов О.С. Теория и технология флотации руд. 2-е изд. М.: Недра, 1990. 363 с.

10. Клебанов О.В., Шубов Л.Я., Щеглова Н.К. Справочник технолога по обогащению руд цветных металлов. Под ред. А.В. Троицкого. М.: Недра, 1974. 472 с. 19.07.2019 г.)

11. https://metallurgy.zp.ua/obogashhenie-rud-flotatsiej/ Обогащение руд флотацией. 16.11.2016. (дата обращения

\section{REFERENCES}

1. Glembockij V.A. Klassen V.I. Flotacionnye metody obogashcheniya. M. «Nedra», 1981

2. Abramov A.A. Flotacionnye metody obogashcheniya. M.: Gornaya kniga, 2008. 711s.

3. Patent №2155716. Opubl. 16.09.2000. Byul. №25.

4. Patent №87159 na poleznuyu model'. Opubl. 27.09.2009 g. Byul. №27. 2002 g. $473 \mathrm{~s}$

5. Shilo N.A. Uchenie o rossypyah. Teoriya rossypeobrazuyushchih rudnyh formacij i rossypej. Vladivostok, Dal'nauka,

6. Elektronnyj resurs: www.twellgroup.ru

7. Patent na izobretenie №2507007 ot $20.02 .2014 \mathrm{~g}$. «Sposob izvlecheniya izbrannyh mineralov iz rudnyh pul'p napornoj flotaciej i ustrojstvo dlya ego osushchestvleniya».

8. Atkinson B.W., Conway C.J. and Jameson G.J. High Efficiency Flotation of Coarse and Fine Coal, paper presented at: High Efficiency Coal Preparation Symposium, SME annual Meeting, AIME 124th Annual Meeting, March 6-9, Denver, Colorado, USA (1995).

9. Bogdanov O.S. Teoriya i tekhnologiya flotacii rud. 2-e izd. M.: Nedra, 1990. $363 \mathrm{s.}$

10. Klebanov O.V., Shubov L.YA., Shcheglova N.K. Spravochnik tekhnologa po obogashcheniyu rud cvetnyh metallov. Pod red. A.B. Troickogo. M.: Nedra, 1974. 472 s. 19.07.2019g.)

11. https://metallurgy.zp.ua/obogashhenie-rud-flotatsiej/ Obogashchenie rud flotaciej. 16.11.2016. (data obrashcheniya

\section{OБ ABTOPE | ABOUT AUTHOR}

Санкин Александр Викторович, канд. филос. наук, доцент, начальник ОМРЦ РПК ССТ ИСТиД (филиал) СКФУ в г. Пятигорске. Автор свыше 170 научных трудов, 2 монографий, 5 изобретений и программных средств. Действительный член РАЕІІ по секции «Ноосферные знания и технологии». Круг научной деятельности - расчеты и моделирование технических систем, наноструктурированных 
материалов, гетероструктур и пленок; разработка технологий получения новых материалов. Sankin Alexander Viktorovich, Candidate of Philosophy, Associate Professor, Head of Sectoral Interregional Resource Center for the Development of Professional Qualifications in the Field of Service and Tourism of the School of Caucasian Hospitality, Institute of Service, Tourism and Design (branch) NCFU in Pyatigorsk. Author of over than 170 scientific papers, 2 monographs, 5 inventions and software. Full member of the Russian Academy of Natural Sciences in the section "Noospheric Knowledge and Technologies". The range of scientific activities - calculations and modeling of technical systems, nanostructured materials, heterostructures and films; development of technologies for obtaining new materials.

Дата поступления в редакцию: 11.09.2019

После рецензирования: 11.10 .2019

Дата принятия к публикации: 01.11.2019 